\title{
Study on the negative influence of mobile phone media on student from ethnic universities and colleges and its countermeasures
}

\author{
Mengtian Cui ${ }^{1,2, a}$ \\ ${ }^{1}$ School of Computer Science \& Technology, Southwest University for Nationalities, 610041, \\ Chengdu, China \\ ${ }^{2}$ School of Computer Science \& Engineering, University of Electronic Science \&Technology of \\ China,610041, Chengdu,China; \\ a happyzg3@163.com
}

\begin{abstract}
Keywords: Mobile Phone Media; Information Technology; Negative Influence; Student from Ethnic Universities and Colleges;

Abstract. The advantage and disadvantage of $n$ mobile phone media is discussed in the paper and the psychological processes on student from ethnic universities and colleges and the significance of researching is analyzed. Meanwhile, two aspects of mobile phone media and its negative effects on mobile phone media and its negative effects on student from ethnic universities and colleges is theoretically analysis from the technology philosophy view point and possible passive mentality that might be present in using mobile phone media by students is discussed. In the end, the relevant strategy's feasibility is proposed to1essen the negative influence on mobile phone media and its negative effects on student of ethnic universities and colleges based the data provided demonstrated and investigating cases.
\end{abstract}

\section{Introduction}

Mobile phone media as the carrier of information dissemination and exchange belong to the scope of technology. Therefore, the Mobile phone media has two sides of the impact on the students possess dual nature. Mobile phone media breaks the constraints of time and space, providing a wealth of information resources to facilitate student learning exchanges. Also, if the Mobile phone medias in the improper application by secondary school students, students learning styles may also lead to alienation, physical decline, moral personality dislocation, language learning weakening and so on. Mobile phone media double impact on the students, especially negative impact on the students Mobile phone media issues, has become the field of information technology is worth pondering[1-7].

\section{Mobile phone media's double impact on the students}

1.1 Mobile phone media bring facilitate on access to information resources, meanwhile, it may affect the learning way of students. With the network technology and communication technology, the number of network information resources grows in geometric progression, the diversification of the presentation to provide students with abundant information resources, to facilitate students in a timely manner to solve problems, develop students' knowledge. Mobile phone media for students of information processing, dissemination provides convenient, but also for the students to copy, paste, copy information resource provides an opportunity of leading the way students learn laziness. Information Resources illustrated something by audio and video and animation, which may weaken the students' the ability to analyze and thinking [2].

1.2 Mobile phone media achieve colorful virtual world, but also may affect the student's physical and mental health. Mobile phone media break the constraints of time, changing the way student exchanges, to provide students with collaborative, individualized counseling and diverse learning styles. Mobile phone media to shorten the physical space, but also likely to expand the students' minds distance, inhibit emotional training. Virtual world to stimulate students' senses, stimulate students interest in learning and entertainment. However, prolonged exposure online media, may lead to "Internet addiction syndrome", resulting in a variety of physical ailments. Meanwhile, 
students may be affected by the virtual world of assimilation, dilute the real world and the virtual world boundaries, alienation values, entice students crimes[3].

1.3 Mobile phone media entertainment ease the psychological pressure, but may affect the student's normal academic. Many student from ethnic universities and colleges use online entertainment, such as chat rooms, network music to ease the psychological pressure. But mixed with a variety of network entertainment pornographic information and individualistic ideology, through computer networks, mobile networks to spread, students easy to bad contact information may distract the learning effort, poor academic performance, excessive indulgence which may also abandoned normal studies.

\section{The analysis of the psychological processes on students using online media}

2.1 Students use actively the network resources for learning, but also may be due to laziness and unknown causes learning motivation. Using Mobile phone media resources can help students learn to solve problems and improve learning efficiency. However, the extensive network of resources, illustrations, students may also bring psychological dependence, Such as Over-reliance on QQ ,search engine, mobile phone and so on .The theoretical thinking about Mobile phone media influence on the students theoretical thinking. Software plagiarism may weaken the students' ability of thinking and analyzing and easy lead to learning of laziness.

2.2 Students use the virtual world to get sensory stimulation, but may lead to decreased self-control physical decline.Mobile phone media are sharing virtual world and chat communication for secondary students. Virtual online games bring students sensory stimulation and obtain happiness to ease the psychological contradictions. However, excessive indulgence virtual world, like smoking "electronic heroin", self-control may fall, resulting in prolonged use of online media that may bring damage to body organs, affecting their healthy growth. Students use network language to simplify communication, at the same time, it may also lead to loss of cognitive ability and the backwards of verbal ability. Students using SMS, QQ, chat rooms and other dissemination network language, its humorous features that will help students' individuality. However, excessive use of Internet language, especially in essay writing, the use of traditional language learning may affect students' language, grammar correctly grasp, even degenerate student's language organization.

2.3 Students use the Internet to meet the spiritual needs of entertainment, but may lead to moral consciousness willpower fade and criminal breeding. Students use the Internet to entertainment, work and rest to meet spiritual needs. But students of willpower, self-protection awareness is not enough, network entertainment violence and sex, and phone sex may corrode students willpower, twisted moral personality of secondary school students, and even breed criminal.

\section{Mobile phone media's negative impact on the students via investigating}

Survey design and implementation [5-7].

(i) Objective of investigation and survey. To better understand the online media negative impact on the students to explore the causes of negative effects, we students use online media to investigate the situation. In this study, students form southwest universities for nationalities are for the survey. We randomly selected two of 500 college students as a sample.

(ii) Methodology. The questionnaires and interviews in per class is used to investigate the situation on students using online media. In order to improve the recovery rate of the questionnaire and efficient, I ask a few instructors collaborative organization questionnaire.

(iii) Investigations content. Questionnaire mainly includes Mobile phone media (Internet and mobile phones) to use the basic situation of the media in the network learning cognitive, physical condition, emotional and moral situation, the evaluation of Mobile phone media. 
Table 1. Mobile phone media double impact on the students

\begin{tabular}{|c|c|c|c|c|}
\hline \multirow{2}{*}{ Impact } & \multicolumn{2}{|c|}{ Mobile phone media double features } & \multicolumn{2}{|c|}{$\begin{array}{l}\text { Psychological on students using mobile } \\
\text { phone }\end{array}$} \\
\hline & Positive impact & Negative impact & $\begin{array}{c}\text { Positive } \\
\text { psychological }\end{array}$ & $\begin{array}{c}\text { Negative } \\
\text { psychological } \\
\end{array}$ \\
\hline Access & $\begin{array}{l}\text { Facilitate } \\
\text { efficiency }\end{array}$ & Laziness & $\begin{array}{l}\text { Positive attitude } \\
\text { towards learning }\end{array}$ & $\begin{array}{c}\text { Motivation } \\
\text { unknown }\end{array}$ \\
\hline Express & Illustration & $\begin{array}{c}\text { Internet addiction } \\
\text { dilute moral } \\
\text { personality } \\
\end{array}$ & $\begin{array}{l}\text { Senses exciting } \\
\text { interest exciting }\end{array}$ & $\begin{array}{l}\text { Decreased } \\
\text { selfcontrol }\end{array}$ \\
\hline $\begin{array}{l}\text { Network } \\
\text { language }\end{array}$ & $\begin{array}{l}\text { Simplify } \\
\text { interaction }\end{array}$ & $\begin{array}{l}\text { Language function } \\
\text { degradation }\end{array}$ & Humor & $\begin{array}{l}\text { Lack of cognitive } \\
\text { ability }\end{array}$ \\
\hline Entertainment & Relieve stress & $\begin{array}{l}\text { Learning distracted } \\
\text { Abandoned learning }\end{array}$ & $\begin{array}{c}\text { Satisfy their spiritual } \\
\text { needs }\end{array}$ & $\begin{array}{c}\text { Dilute the moral } \\
\text { consciousness }\end{array}$ \\
\hline
\end{tabular}

(iv) Implementation Research. We were on the southwest university for nationalities 1st primary for students online media usage survey, sample survey questionnaire. including the Internet and mobile phones two links survey uniform distribution, questionnaires, anonymous, independently completed within 20 minutes way. A total of 500 questionnaires, 460 were recovered, the recovery rate was $92 \%$, of which 382 valid questionnaires, questionnaires, the effective rate $93.2 \%$. A total of 156 questionnaires the males, accounting for 47\%; The females are 211 , accounting for 53\%.

(v) Data Statistics and Analysis. Microsoft Office Excel 2003 software is used to collect the data for statistical processing, the survey results are described statistical analysis.

\section{Analysis of survey results.}

(i) The basic situation of students use Mobile phone media. The number of students use Mobile phone media. Survey shows that up to $82 \%$ of the students have Internet experience, $49 \%$ of students have cell phones. Showed that students using online media more common. Therefore, the impact of online media on the students will be involved in most of the groups, rather than individual students.

(ii) The purpose of using online media. From Table 1 it can be seen, the case of students use the Internet as: chat with friends as high as $81 \%$; followed by watching network TV or listening to music (65.5\%): Download the proportion of 34\%: ratio of learning 33.8\%. Showed that students using the Internet in the form of a single, primary school students online entertainment is the main purpose. Side shows the network information resources are not impact on the students take full advantage of.

Table 2. The purpose of using online media

\begin{tabular}{|c|c|c|c|c|c|c|}
\hline Chat & $\begin{array}{l}\text { Watching TV, Online } \\
\text { Music \&Film }\end{array}$ & Download & Learning & Game & Web & Email \\
\hline $81 \%$ & $65.5 \%$ & $34 \%$ & $33.8 \%$ & $48 \%$ & $69 \%$ & $19 \%$ \\
\hline
\end{tabular}

Table 3. The frequency and time of students access mobile phone

\begin{tabular}{|l|c|c|c|c|}
\hline \multirow{2}{*}{ Frequency of online } & $\begin{array}{c}1 \text { time } \\
\text { per week }\end{array}$ & $\begin{array}{c}3 \text { times } \\
\text { per week }\end{array}$ & $\begin{array}{c}6 \text { times } \\
\text { per week }\end{array}$ & $\begin{array}{c}\text { All times } \\
\text { per week }\end{array}$ \\
\cline { 2 - 5 } & $5 \%$ & $5.1 \%$ & $8.2 \%$ & $90 \%$ \\
\hline $\begin{array}{l}\text { Average time spent } \\
\text { online per time }\end{array}$ & Within1 hour & $\begin{array}{c}\text { Between 1 and 2 } \\
\text { hours }\end{array}$ & $\begin{array}{c}\text { Between } 2 \\
\text { and 4 hours }\end{array}$ & $\begin{array}{c}\text { More than } 4 \\
\text { hours }\end{array}$ \\
\cline { 2 - 5 } & $26 \%$ & $39 \%$ & $42 \%$ & $8 \%$ \\
\hline
\end{tabular}

Table 4. Online time impact on the body

\begin{tabular}{|c|c|c|c|r|}
\hline \multirow{3}{*}{ Behavior } & $\begin{array}{c}\text { Watching TV, } \\
\text { Online Music\&film }\end{array}$ & Eye Fatigue & Neck Pain & No Effect \\
\cline { 2 - 5 } & $31 \%$ & $48 \%$ & $57 \%$ & $7.5 \%$ \\
\hline
\end{tabular}


Table3 shows the frequency and students from ethnic universities and colleges access the Internet each time it takes to meet the basic learning needs of students and the physical and mental development. 1 week accounted for 5\%, three times a week about 5.1\%. Meanwhile, the data show that $5 \%$ of tudents over the Internet frequently, $8.2 \%$ of students spend more time, which will affect their normal academic and physical development. Students use the network for a long time, more or less affect the body. From Table 4 it can be seen, up to $48 \%$ of students feel eye fatigue, $57 \%$ of students feel neck pain. Through field interviews, we learned that students on time on the Internet, there is numbness in the hand, arm pain, and other symptoms are not serious learning.

Through survey data, we learned that students believe that the network entertainment addictive, it is difficult to control their proportion up to 75\%; entertainment network, while she herself can not control 23\%; always want to play the game, do not want to go to school, unwilling to do homework the proportion of $10 \%$; networks affect the body's 54\%. From Figure 4 we can see that students encounter difficulties in the network, in addition to $57 \%$ of students to ask teachers first, but up to $90 \%$ of students with Baidu, Google and other search engines to solve the problem that students web search engine psychological dependence is relatively strong, easy to produce mental laziness.

\section{Conclusions}

The survey data show that online media on the students from ethnic universities and colleges really brought some negative effects. Field interviews I learned that most students can face online media, online media that the advantages outweigh the disadvantages, in promoting learning exchanges, but also bring some negative impact. Network communication media in promoting student learning, but also give students some impact. This paper mainly through questionnaires and field interviews, etc., in order to hibiscus and hibiscus junior high school, for example, carry out specific research to understand the students in the study of cognitive, physical condition, moral and emotional aspects there are some negative effects. Analysis of the causes of negative impacts, the proposal for the follow-up strategy to pave the way.

\section{Acknowledgments}

This work was financially supported by the Fundamental of Sichuan Key Research Institute of Humanities and social science of China West Normal University Sichuan Province college students' Ideological and political education research center(CSZ11005), the Fundamental of the Leaders in academic and technical training fund of Sichuan Province,China Postdoctoral Science Foundation(2013M540704),Research Special Funds for the Post-doctor of Sichuan Province and the National Natural Science Foundation of China(61379019).

\section{References}

[1] Jane M. Healy. Failure To Connect: How Computers Affect Our Children's Minds for Better or Worse[M].New York:Simon St Schusmr,1998.

[2] Shazia Mumtaz. Children's enjoyment and perception of computer use in the home and the school[J].Computer\&Education,2001(5):347-362.

[3] Joanne Cantor, Barbara J. Wilson. Media and Violence: Intervention Strategies or Reducing Aggression[J]. Media Psychology, 2003(11):363-403.

[4] Information on http://erendip. brynmawr.edu/exchange /node/1723.

[5] Information on http:/www.etmie,Net.cn/HTML/1259045841d1575..Html,.2010/3/12

[6] Information on.http:/www.etmie,Net.cn/uploadfiles/PDF/2009/4/13/164657.pdf, 2012/4/14.

[7] Information on Http://www.cnnic.net.cn/uploadfiles/dod2009/1/13/92209.doe,2012/4/14. 